УДК 339.92

DOI: https://doi.org/10.32782/2224-6282/167-10

Дараган А. В.

аспірант кафедри міжнародного бізнесу та фінансів, Національний технічний університет «Харківський політехнічний інститут»

Геворкян А. Ю.

доцент кафедри міжнародного бізнесу та фінансів,

Національний технічний університет «Харківський політехнічний інститут»

\section{ФОРМУВАННЯ СКЛАДНИКІВ ФІНАНСОВОГО ПОТЕНЦІАЛУ ПІДПРИЕМСТВА}

Darahan Anton, Gevorkyan Artem

National Technical University «Kharkiv Politechnical Institute»

Сьогодні фінансовий потенціал підприємства є одним із базових показників успішного функиіонування підприємства. Для ефективного управління фінансовим потенціалом існує необхідність чіткого визначення його складників, які формуватимуть потужності підприсмства. Складні сучасні економічні умови, загострення соціальних та епідеміологічних проблем, нестабільна законодавча база вимагають від національних підприємств створення системи, яка б давала змогу ефективно використовувати всі наявні та потенційні фінансові ресурси, швидко реагувати на зміни в навколишньому середовищі та забезпечувати високі фінансові результати не лише в поточному періоді, а й у довгостроковій перспективі. Слід також зазначити, щзо у статті визначено функиї̈ фінансового потенціалу та його риси. Визначено, щзо до його функиій входять ресурсний, інформаційний, організаиійний та аналітичний складники. Сформовано основні етапи, за якими відбувається оцінка фінансового потенціалу підприємства на основі його складників.

Ключові слова: фінансовий потенціал, складник, підприємство, ринок, конкурентоспроможність, ринок, показник, підвищення, аналіз.

\title{
FORMATION OF COMPONENTS OF FINANCIAL POTENTIAL OF THE ENTERPRISE
}

Today the financial potential of the enterprise is one of the basic indicators of successful operation of the enterprise. For effective management of financial potential there is a need to clearly define its components that will form the capacity of the enterprise. The essence of financial potential is not so much in the availability of financial resources in a particular period of time, as in the ability of the company to form and reproduce the necessary assets in full with minimal costs and in a short time. The level of financial potential directly affects the level of competitiveness of the enterprise - the ability of the enterprise to compete in markets with producers and sellers of similar goods by providing higher quality, affordable prices, creating comfortable conditions for buyers and consumers. Difficult modern economic conditions, aggravation of social and epidemiological problems, unstable legal framework require national enterprises to create a system that would allow efficient use of all available and potential financial resources, respond quickly to changes in the environment and ensure high financial results. not only in the current period, but also in the long run. To date, very little research has been conducted in the scientific literature on the components of financial potential, which denies today's scientists in-depth study of the functioning of financial potential. Thus, we propose to consider the financial potential of the following elements: resource component, organizational component, information component, analytical component. To effectively use the components of financial potential, it is also necessary to take into account entrepreneurial skills (human factor). After all, each company needs to adequately assess current and future financial opportunities and make effective decisions to optimize financial resources. In addition, the management system itself also plays an important role. It should also be noted that the article defines the functions of financial potential and its features. It is determined that its functions include: resource, information, organizational and analytical component. The basic stages at which there is an estimation of financial potential of the enterprise on the basis of its components are formed.

Keywords: financial potential, component, enterprise, market, competitiveness, market, indicator, increase, analysis.

JEL classification: L32, G31

Постановка проблеми. В умовах, коли підприємства зменшують свої витрати у зв'язку з пандемією COVID-19, яка здійснила сильний економічний вплив на функціонування бізнесу в усьому світі, питання формування складників фінансового потенціалу $є$ дуже актуальним. Фінансовий потенціал стає чинником, який впливає на збереження конкурентоспроможності підприємства та зменшення ризиків банкротства. Однак нині не існує єдиної думки щодо складників фінансового потенціалу. Для розроблення інвестиційної стратегії, фінансового плану та обгрунтування доцільності тих чи інших дій необхідно чітко сформу- вати та дати характеристику складників фінансового потенціалу.

Аналіз останніх досліджень і публікацій. Дослідженню фінансового потенціалу присвячено багато наукових праць вітчизняних та зарубіжних учених, серед них: В.А. Міщенко, Т.Ю. Назарова, П.Г. Перерва, А.І. Яковлєв, І.О. Бланк, Н.М. Давиденко, В.Г. Герасимчук, Н.С. Краснокутська, Г.В. Ситник, І. Шовкун, I. Марченко, Дж. Сідел, Е.Ф. Брігхем та ін. Але недостатньо уваги приділялося дослідженню складників фінансового потенціалу, внаслідок чого існує певне непорозуміння у його функціонуванні. 
Мета статті полягає у формуванні складових елементів фінансового потенціалу на основі виявлення додаткових фінансових ресурсів.

Виклад основного матеріалу. Велике значення для успішного функціонування підприємства має ефективне використання його фінансового потенціалу. На його основі формується відповідна ресурсна база, яка допомагає у довгостроковій перспективі профінансувати відповідні проєкти різних департаментів та зберегти свої виробничі потужності.

Складні сучасні економічні умови, загострення соціальних і епідеміологічних проблем, нестабільна правова база вимагають від вітчизняних підприємств створення такої системи, яка б дала можливість ефективно використовувати всі наявні та потенційно можливі фінансові ресурси, швидко реагувати на зміни зовнішнього середовища і забезпечувати досягнення високих фінансових результатів не тільки в поточному періоді, а й у довгостроковій перспективі [5].

Сьогодні фінансовий потенціал виконує для підприємства такі функції [1]:

- розподільчу: забезпечує розподіл та перерозподіл фінансових активів між суб'єктами економічних відносин відповідно до попиту, пропозиції, потреб, доцільності, мотивації, цілей та стратегії розвитку;

- відтворювальну: формує достатню кількість фінансових активів у розпорядженні суб'єктів економічних відносин для забезпечення їх фінансово-господарської діяльності;

- контрольну: забезпечує контроль над формуванням, накопиченням, використанням та відтворенням


повідно до чинної нормативно-правової бази, поточних та довгострокових пріоритетів його розвитку;

- індикативну: дає змогу визначати фінансовий стан, тенденції, ризики, спроможність суб'єкта економічних відносин забезпечити процес відтворення для виконання завдань та цілей.

Слід відзначити, що фінансовий потенціал має такі риси:

- призначення або мета, з якою підприємство формує його тренди, які суб'єкт господарювання спостерігає у процесі свого розвитку;
- функціонування у системі діяльності підприємства;

- взаємодія усіх складників фінансового потенціалу.

Сутність фінансового потенціалу полягає, насамперед, не стільки у наявності фінансових ресурсів у конкретний проміжок часу, як у здатності підприємства формувати та відтворювати необхідні активи у повному обсязі з мінімальними витратами та у стислі терміни. Від рівня фінансового потенціалу безпосередньо залежить рівень конкурентоспроможності підприємства - здатності підприємства конкурувати на ринках з виробниками й продавцями аналогічних товарів за допомогою забезпечення більш високої якості, доступних цін, створення зручних умов для покупців, споживачів [2].

Сьогодні у науковій літературі дуже мало проведено досліджень щодо складників фінансового потенціалу, що заважає науковцям у глибокому дослідженні функціонування фінансового потенціалу. Таким чином, нами пропонується розглядати фінансовий потенціал за такими елементами:

Для ефективного використання складників фінансового потенціалу необхідно також брати до уваги підприємницькі здібності (людський фактор). На кожному підприємстві необхідно адекватно оцінювати поточні та перспективні фінансові можливості і приймати ефективні рішення щодо оптимізації фінансових ресурсів. Окрім того, грає також важливу роль сама система управління. За неефективної управлінської системи втрачаються складові елементи фінансового потенціалу, що призводить до неефективності діяльності підприємства та ускладнює досягнення необхідного рівня конкурентоспроможності підприємства [2].

Фінансовий потенціал підприємства також поділяють на короткостроковий та довгостроковий. Необхідність у такому поділі полягає у тому, що періоди та умови існування фінансового потенціалу відрізняються, адже у довгостроковому періоді виникає значно більша кількість чинників ризику, що мають характер негативних впливів [2].

У роботі I.C. Марченко зазначено, що оцінювання фінансового потенціалу підприємства включає у себе аналіз динаміки джерел формування власного і пози-

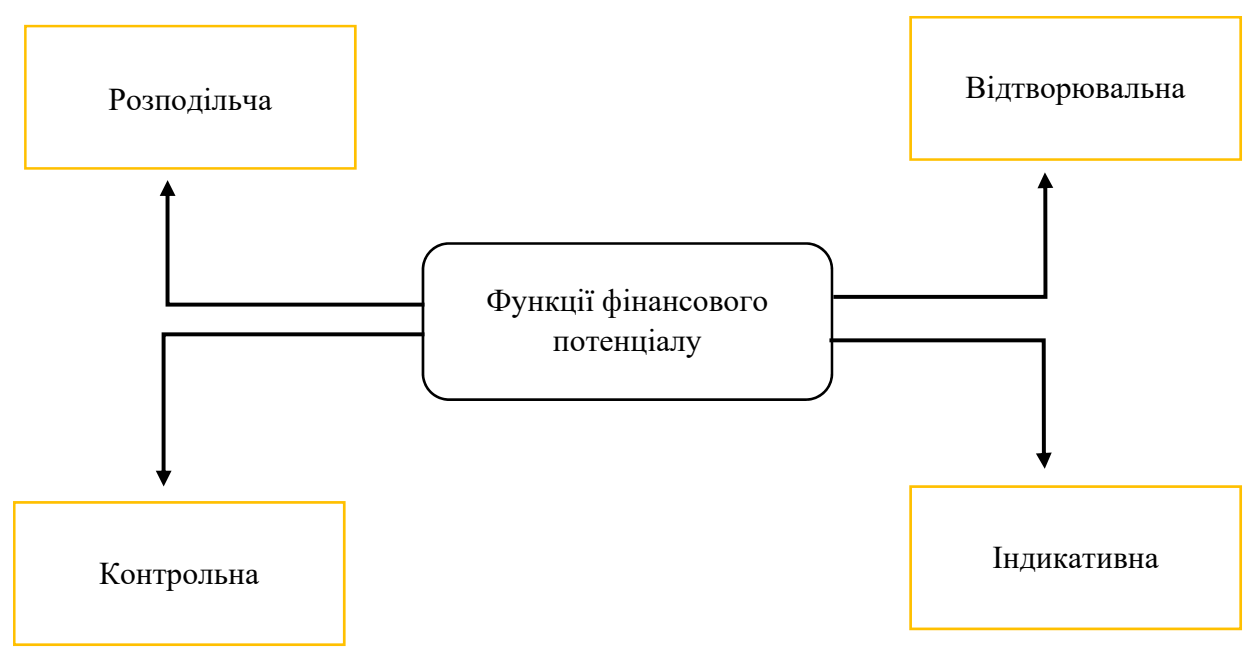

Рис. 1. Функції фінансового потенціалу

Джерело: розроблено авторами 


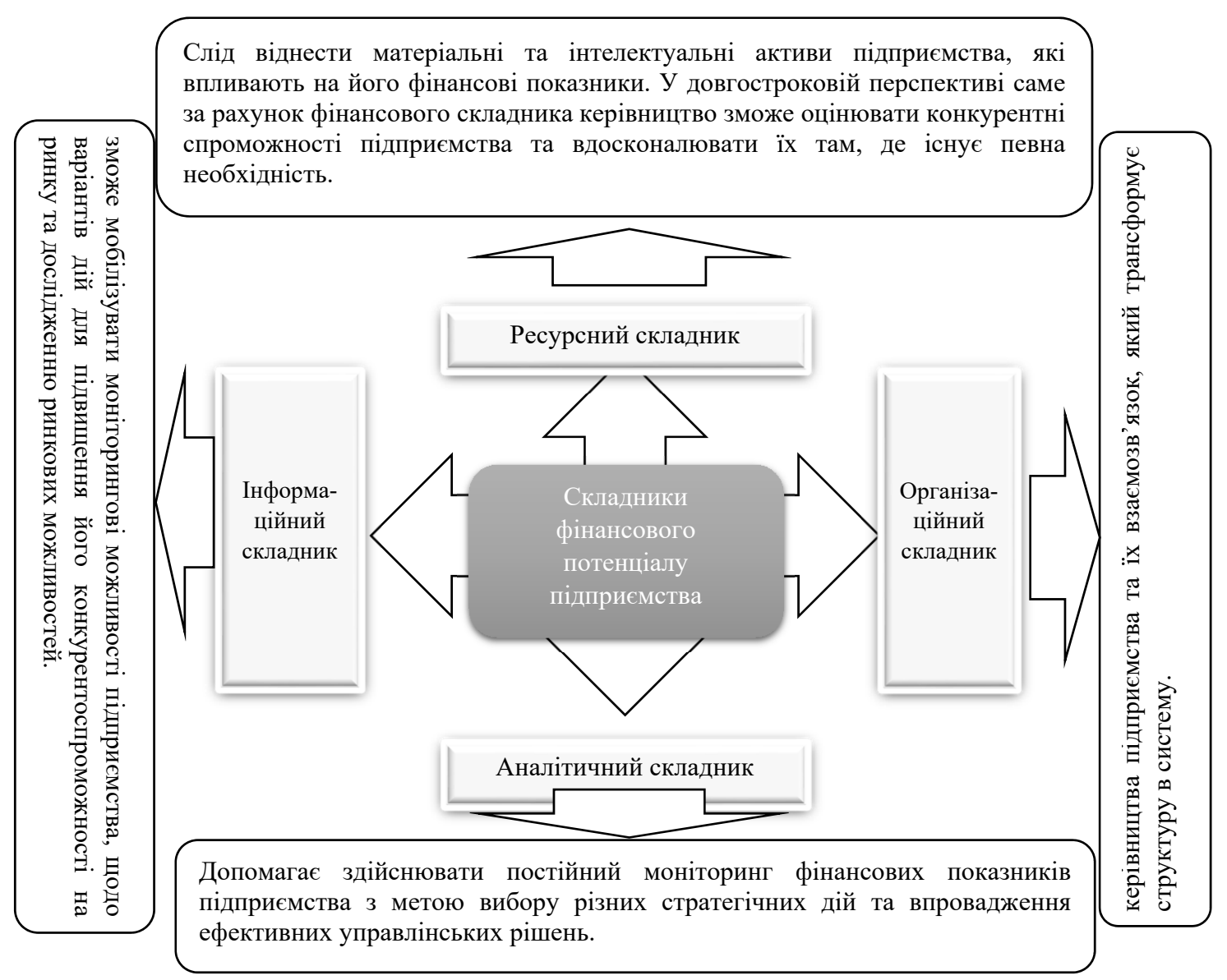

Рис. 2. Елементи фінансового потенціалу підприємства

Джерело: розроблено авторами

кового капіталу, динаміки оборотності капіталу; визначення показників, що характеризують ліквідність, платоспроможність і фінансову стійкість підприємств; оцінювання потенціалу стійкого розвитку та аналіз динаміки рентабельності, аналіз основних первинних і вторинних показників економічного потенціалу [3].

Проводити оцінювання фінансового потенціалу підприємства важливо як для внутрішніх, так і зовнішніх користувачів інформації. За умов оптимального використання фінансового потенціалу підприємство збільшує свою ринкову вартість, що є сигналом для потенційних інвесторів, кредиторів, акціонерів, державних структур та інших зовнішніх суб'єктів оцінювання щодо доцільності інвестування коштів у досліджуване підприємство та його платоспроможності [4].

Можна виділити основні етапи, за якими відбувається оцінка фінансового потенціалу підприємства на основі його складників [4]:

- аналіз інформації для визначення загальної вартості обігу фінансових ресурсів підприємства та можливих резервів нарощування їх обсягу;

- визначення показників, за якими відбуватиметься оцінка ефективності використання фінансового потенціалу;
- формулювання висновків щодо якості управління фінансовим потенціалом на базі вибраних раніше показників;

- прийняття управлінських рішень щодо зміни фінансового потенціалу у напрямі стратегічного бачення розвитку підприємства.

Висновки. Таким чином, фінансовий потенціал відіграє важливу роль у підвищенні конкурентоспроможності підприємства як на внутрішньому ринку, так i на зарубіжному. Подальші дослідження повинні бути сконцентровані на аналізі досяжності певного рівня фінансового потенціалу на підприємствах машинобудування України. Це дасть змогу дотримання ефективної фінансової стратегії підприємства у достроковий період, а також підвищення ефективності господарської діяльності кожного підприємства. Слід зазначити, що до елементів фінансового потенціалу необхідно віднести ресурсний, організаційний, інформаційний та аналітичний складники, усі вони зможуть сформувати фінансовий потенціал підприємства, який буде базовим показником під час оцінки роботи підприємства на ринку та демонструватиме рівень конкурентоспроможності, адже оцінка фінансового потенціалу компанії важлива як для внутрішніх, так і для зовнішніх користувачів інформації.

Список використаних джерел:

1. Кучер Г.В. Фінансовий потенціал як економічна категорія. Актуальні проблеми економіки. 2014. № 9. С. 46-52.

2. Бова В.А., Хринюк О.С. Сутність фінансового потенціалу підприємства. Актуальні проблеми економіки та управління. 2017. Вип. 11. Електронні текстові дані (1 файл: 409 Кбайт). Назва 3 екрана. 
3. Марченно I.C. Рейтингова оцінна економічного потенціалу підприємств важного машинобудування. URL: http:j/ev.pios.edi.ia//coptept/reitipgova-otsipka-ekopotichpogo-poteptsiali-pidprietstv-vazhkogotashipobidivappya-miko/aiv.

4. Оцінка фінансового потенціалу підприємства / О.А. Бондар та ін. Економічний вісник Національного гірничого універсиmemy. 2017. № 4. C. 161-165. URL: http://nbuv.gov.ua/UJRN/evngu_2017_4_21.

5. Блащак Б.Я. Фінансовий потенціал у структурі потенціалу підприємства. Вчені записки ТНУ імені B.I. Вернадського. Серія «Економіка і управління». 2019. Т. 30(69). № 3. С. 74-78.

\section{References:}

1. Kucher G.V. (2014) Finansoviy potentsial yak yekonomichna kategoriya. Aktualni problemy ekonomiky, no. 9, pp. 46-52.

2. Bova V.A., Khrinyuk O.S. (2017) Sutnist' finansovogo potentsialu pidpriemstva. Aktualni problemi yekonomiki ta upravlinnya: zbirnik naukovikh prats molodikh vchenikh. Yelektronni tekstovi dani (1 fayl: 409 Kbayt). Vip. 11.

3. Marchenno I.S. Reytingova otsinna yenonomichnogo potentsialu pidpriemstv vazhnogo mashinobuduvannya. Available at: http:j/ev.pios.edi.ia//coptept/reitipgova-otsipka-ekopotichpogo-poteptsiali-pidprietstv-vazhkogotashipobidivappya-miko/aiv.

4. Bondar O.A., Kulikov P.M., Shkuropat O.G., Kapinos O.M. (2017) Otsinka finansovogo potentsialu pidpriemstva. Yekonomichniy visnik Natsional'nogo girnichogo universitetu, no. 4, pp. 161-165. Available at: http://nbuv.gov.ua/UJRN/evngu_2017_4 21.

5. Blashchak B.Ya. (2019) Finansoviy potentsial u strukturi potentsiau pidpriemstva. Vcheni zapiski TNU imeni V.I. Vernads'kogo. Seriya: Yekonomika i upravlinnya. T. 30 (69), no. 3, pp. 74-78. 